\title{
AUTHOR INDEX FOR VOLUME 97
}

ALI, MD F., THOMAS, D. K. and VASUDEVARAO, A.; Toeplitz determinants whose elements are the coefficients of analytic and univalent functions

ALIABADI, M.; A note on the fundamental theorem of algebra

BALLESTER-BOLINCHES, A. and PEDRAZA-AGUILERA, M. C.; On a theorem of Kang and Liu on factorised groups

BHIM, L.; Polynomial bounds for solutions to boundary value and obstacle problems with applications to financial derivative pricing

BREMNER, A.; On perfect $K$-rational cuboids

BRZDĘ, J.; see EL-FASSI, IZ.

CAIN, B. E.; Improved inequalities for the numerical radius: when inverse commutes with the norm

CHEN, S. L. and PONNUSAMY, S.; Landau's theorem for solutions of the $\bar{\partial}-$ equation in Dirichlet-type spaces

CHEN, X. and LEWIS, M. L.; Itô's theorem and monomial Brauer characters II

CHMAJ, A.; Existence of travelling waves in the fractional Burgers equation

CHOI, C.-K.; Stability of an exponential-monomial functional equation

CRINGANU, J.; Inequalities associated with ratios of gamma functions

CROOKS, P.; An equivariant description of certain holomorphic symplectic varieties

DE GIOVANNI, F. and RUSSO, A.; Groups of finite normal length

DE MATTOS, D.; see MORITA, A. M. M.

DEVHARE, S., JOSHI, V. and LAGRANGE, J.; On the complement of the zero-divisor graph of a partially ordered set

DEY, P.; Nonlinear thermomagnetic instabilities in ferromagnetic nanofluids

DOUBTSOV, E.; Integral means of holomorphic functions as generic logconvex weights

EL-FASSI, IZ. and BRZDEKK, J.; On the hyperstability of a pexiderised $\sigma$-quadratic functional equation on semigroups

FERREIRA, L. A.; Finitely stable additive bases

GABRIYELYAN, S. S. and MORRIS, S. A.; Subspaces of the free topological vector space on the unit interval

GHODSI, M.; Nonstandard estimation for the von Mises Fisher distribution

GLOGIĆ, E.; see MILOVANOVIĆ, I.

GRANTHAM, A.; Mathematical tools for maximising renewable energy use in electricity supply

GUNAWAN, H., HAKIM, D. I., NAKAI, E. and SAWANO, Y.; The Hardy and Heisenberg inequalities in Morrey spaces

GUO, W.; see ZHAO, G.

HA, L. K.; $L^{p}$-approximation of holomorphic functions on a class of convex domains

HAKIM, D. I.; see GUNAWAN, H. 
HASSANI, S.; Optimality conditions for nonsmooth optimisation problems via generalised derivatives

HONG, S. A.; see LIN, Z. B.

HORBACZEWSKA, G. and LINDNER, S.; Density, Smital property and quasicontinuity

HOYTE, R. A.; Generalisations of the Doyen-Wilson theorem

HU, B., HUANG, J. and SKIBA, A. N.; A generalisation of finite PT-groups 396

HU, X., ZHANG, Y.-Q. and ZHANG, Y.-B.; Quadrilateral-tree planar Ramsey numbers

HUANG, J.; see HU, B.

HUJDUROVIĆ, A.; On some properties of quasi-distance-balanced graphs $\quad 177$

HULL, M. and KAPOVICH, I.; Counting conjugacy classes in $\operatorname{Out}\left(F_{N}\right)$

HUSSAIN, M. and WANG, W.; Two-dimensional shrinking target problem in beta-dynamical systems

JIA, W. and TAN, D.; Wigner's theorem in $\mathcal{L}^{\infty}(\Gamma)$-type spaces

JOHNSTON, S. T.; Mathematical models for quantifying collective cell behaviour

JONES, L. and PHILLIPS, T.; An infinite family of ninth degree dihedral polynomials

JOSHI, V.; see DEVHARE, S.

JUNG, I. B., KO, E. and PEARCY, C.; Almost invariant half-spaces for operators on Hilbert space

KADETS, V. and ZAVARZINA, O.; Nonexpansive bijections to the unit ball of the $\ell_{1}$-sum of strictly convex Banach spaces

KAPOVICH, I.; see HULL, M.

KAZARIN, L. S., MARTÍNEZ-PASTOR, A. and PÉREZ-RAMOS, M. D.; Finite trifactorised groups and $\pi$-decomposability

KO, E.; see JUNG, I. B.

KOWALCZYK, B., LECKO, A. and SIM, Y. J.; The sharp bound for the Hankel determinant of the third kind for convex functions

LAGRANGE, J.; see DEVHARE, S.

LAHIRI, I.; An entire function sharing two values with its linear differential polynomial

LAY, J. P. S.; Improving an inequality for the divisor function

LAZAAR, S., RICHMOND, T. and SABRI, H.; Homogeneous functionally Alexandroff spaces

LÊ, Q. T.; Alexander polynomials of complex projective plane curves 386

LECKO, A.; see KOWALCZYK, B.

LEWIS, M. L.; see CHEN, X.

LI, J.-W. and TANG, M.; Partitions of the set of nonnegative integers with the same representation functions

LI, Y., LU, Y. and YU, T.; The essential norms of composition operators on weighted Dirichlet spaces 
LIN, Z. B. and HONG, S. A.; More on a certain arithmetical determinant

LINDNER, S.; see HORBACZEWSKA, G.

LORANTY, A. and PAWLAK, R. J.; On functions attracting positive entropy

LU, Y.; see LI, Y.

LUCA, F., POLANCO, G. and ZUDILIN, W.; A variation on the theme of Nicomachus

LUZIA, N.; A simple proof of the strong law of large numbers with rates

MACOURT, S.; Visible points on exponential curves

MAHMOODI, A.; $\varphi$-contractibility and $\varphi$-Connes amenability coincide with some older notions

MAHMOUDI, M. G.; Products of rotations by a given angle in the orthogonal group

MARTÍNEZ-PASTOR, A.; see KAZARIN, L. S.

MATEJIĆ, M.; see MILOVANOVIĆ, I.

MENG, Q.; Weak Haagerup property of $W^{*}$-crossed products

MILOVANOVIĆ, E.; see MILOVANOVIĆ, I.

MILOVANOVIĆ, I., MATEJIĆ, M., GLOGIĆ, E. and MILOVANOVIĆ, E.; Some new lower bounds for the Kirchhoff index of a graph

MOHAPATRA, M. R. and SAHOO, S. K.; Mapping properties of a scale invariant Cassinian metric and a Gromov hyperbolic metric

MONTAGANTIRUD, P. and THAIKUA, W.; Continuity on generalised topological spaces via hereditary classes

308

218

119

MORALES, C. A., THIEULLEN, P. and VILLAVICENCIO, H.; Lyapunov exponents on metric spaces

MORITA, A. M. M., DE MATTOS, D. and PERGHER, P. L. Q.; The cohomology ring of orbit spaces of free $\mathbb{Z}_{2}$-actions on some Dold manifolds

MORRIS, S. A.; see GABRIYELYAN, S. S.

NAKAI, E.; see GUNAWAN, $\mathrm{H}$.

O'NEILL, C. and PELAYO, R.; Realisable sets of catenary degrees of numerical monoids

PANDEY, P. P.; The $3 k-4$ theorem for ordered groups

PASQUIER, B.; The ocean's global iron, phosphorus and silicon cycles: inverse modelling and novel diagnostics

PAWLAK, R. J.; see LORANTY, A.

PEARCY, C.; see JUNG, I. B.

PEDRAZA-AGUILERA, M. C.; see BALLESTER-BOLINCHES, A. 54

PELAYO, R.; see O'NEILL, C.

PÉREZ-RAMOS, M. D.; see KAZARIN, L. S. 218

PERGHER, P. L. Q.; see MORITA, A. M. M. 340

PHILLIPS, T.; see JONES, L.

$\begin{array}{ll}\text { POLANCO, G.; see LUCA, F. } & 367\end{array}$

PONNUSAMY, S.; see CHEN, S. L. $\quad 80$

QIAN, G.; see YANG, Y. 406 
RAEBURN, I.; On graded $C^{*}$-algebras $\quad 127$

RICHMOND, T.; see LAZAAR, S. 331

RUSSO, A.; see DE GIOVANNI, F. 229

SABRI, H.; see LAZAAR, S. 331

SAHOO, S. K.; see MOHAPATRA, M. R. 141

SAPIR, O.; Lee monoids are nonfinitely based while the sets of their isoterms are finitely based

422

SAWANO, Y.; see GUNAWAN, H. $\quad 480$

SIM, Y. J.; see KOWALCZYK, B.

SKAŁBA, M.; Note on Lehmer-Pierce sequences with the same prime divisors 11

SKIBA, A. N.; see HU, B.

TAN, D.; see JIA, W. $\quad 279$

TANG, M.; see LI, J.-W. $\quad 200$

TANG, M.; see WANG, W.

THAIKUA, W.; see MONTAGANTIRUD, P. 320

THIEULLEN, P.; see MORALES, C. A. 153

THOMAS, D. K.; see ALI, MD F. 253

TOWNSEND, K. D.; Classification of reflection subgroups minimally $\begin{array}{ll}\text { containing } p \text {-Sylow subgroups } & 57\end{array}$

TSARTSAFLIS, I.; Cohomology of filiform Lie algebras over fields of
characteristic two

VASUDEVARAO, A.; see ALI, MD F. 253

VILLAVICENCIO, H.; see MORALES, C. A. 153

VIROSZTEK, D.; Applications of an intersection formula to dual cones $\quad 94$

WANG, W.; see HUSSAIN, M.

WANG, W. and TANG, M.; A note on the Erdős-Graham theorem 363

YANG, Y. and QIAN, G.; On p-parts of conjugacy class sizes of finite groups 406

YANG, Y. and ZHANG, D.; Deforming a convex domain into a disk by Klain's $\begin{array}{ll}\text { cyclic rearrangement } & 313\end{array}$

$\begin{array}{ll}\text { YU, T.; see LI, Y. } & 297\end{array}$

YU, X.; see ZHAO, G.

ZAVARZINA, O.; see KADETS, V. 285

ZHANG, D.; see YANG, Y. $\quad 313$

ZHANG, Y.-B.; see HU, X. 194

ZHANG, Y. H.; A remark on the tracial Rokhlin property 492

ZHANG, Y.-Q.; see HU, X. 194

ZHAO, G., GUO, W. and YU, X.; Fractional integral operators on $\alpha$-modulation spaces in the full range $\quad 499$

ZUDILIN, W.; see LUCA, F. 


\section{INFORMATION FOR AUTHORS}

The Bulletin of the Australian Mathematical Society aims at quick publication of original research in all branches of mathematics. To ensure speedy publication, only articles which are sufficiently well presented, able to be published without revision, and which are judged by the Editor (often in consultation with an Associate Editor) to be competitive are refereed. This policy is in the interests of authors, as a quick rejection is better than a slow rejection. The Bulletin receives more than five times the material that can be published, therefore there are many commendable papers not accepted. Editorial decisions on acceptance or otherwise are taken quickly, normally within a month of receipt of the paper. Papers are accepted only after peer review.

Manuscripts are accepted for review with the understanding that the same work is not concurrently submitted elsewhere. For a paper to be acceptable for publication, not only should it contain new and interesting results, but also

(i) the exposition should be clear and attractive, and

(ii) the manuscript should be in publishable form, without revision.

Further information regarding these requirements may be found through our website www.austms.org.au/Bulletin. Authors are asked to avoid, as far as possible, the use of mathematical symbols in the title.

Articles should be prepared in $\mathrm{ET}_{\mathrm{E}} \mathrm{X}$ using $\mathcal{A}_{\mathcal{M}} \mathcal{S}$-LTEX packages and submitted as a PDF file via our journal management system, at www.austms.org.au/Publications/Submissions/BAustMS. This permits authors to track their papers through the editorial process. Recent versions of $\mathrm{T}_{\mathrm{E}} \mathrm{X}$ are able to produce PDF files directly. A LTTEX class file for the Bulletin can be downloaded from the website. Authors who need assistance may email the secretary of the Bulletin at editor@bulletin.austms.org.au.

Authors are advised to keep copies of all files of the submitted article; the Bulletin will not accept responsibility for any loss.

\section{EDITORIAL POLICY}

1. References. Arrange references alphabetically (by surname of the first author) and cite them numerically in the text. Ensure the accuracy of the references: authors' names should appear as in the work quoted. Include in the list of references only those works cited, and avoid citing works which are in preparation or submitted. Where the work cited is not readily accessible (for example, a preprint) a copy of the article should be included with your submission.

\section{Abstracts.}

1. Each paper must include an abstract of not more than 150 words, which should contain a brief but informative summary of the contents of the paper, but no inessential details.

2. The abstract should be self-contained, but may refer to the title.

3. Specific references (by number) to a section, proposition, equation or bibliographical item should be avoided.

3. Subject Classification and Key Words. Authors should include a few key words and phrases and one or more classification numbers, following the American Mathematical Society 2010 Mathematics Subject Classification for all codes. Details of this scheme can be found on the web at www.ams.org/msc.

4. Abstracts of PhD Theses. The Bulletin endeavours to publish abstracts of all accepted Australasian $\mathrm{PhD}$ theses in mathematics. One restriction, however, is that the abstract must be received by the Editor within six months of the degree being approved.

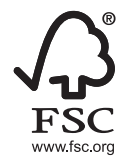

This journal issue has been printed on FSC-certified paper and cover board. FSC is an independent, non-governmental, not-for-profit organisation established to promote the responsible management of the world's forests. Please see www.fsc.org for information. 


\section{Table of Contents}

Visible points on exponential curves

Macourt, $S$.

Finitely stable additive bases

Ferreira, L. A.

A note on the Erdős-Graham theorem

Wang, W. \& Tang, $M$.

A variation on the theme of Nicomachus

Luca, F, Polanco, G. \& Zudilin, W.

Improving an inequality for the divisor function

Lay, F. P. S.

A note on the fundamental theorem of algebra

Aliabadi, $M$.

Alexander polynomials of complex projective plane curves

Lê. Q.T.

A generalisation of finite $\boldsymbol{P T}$-groups

$H u, B$., Huang, f. \& Skiba, $A$. $\mathcal{N}$.

On $p$-parts of conjugacy class sizes of finite groups

Yang, $Y$. \& Oian, $G$.

Counting conjugacy classes in $\operatorname{Out}\left(\boldsymbol{F}_{N}\right)$

Hull, M. \& Kapovich, I.

Lee monoids are nonfinitely based while the sets of their isoterms are finitely based Sapir, $O$.

The sharp bound for the Hankel determinant of the third kind for convex functions

Kowalczyk, B., Lecko, A. E Sim, Y. J.

$L^{p}$-approximation of holomorphic functions on a class of convex domains

Ha, L. K.

Inequalities associated with ratios of gamma functions

Cringanu, 7 .

On the hyperstability of a pexiderised $\sigma$-quadratic functional equation on semigroups

EL-Fassi, Iz. \& Brzdek, J.

Stability of an exponential-monomial functional equation

Choi, C. - K

The Hardy and Heisenberg inequalities in Morrey spaces

Gunawan, H., Hakim, D. I., Nakai, E. \& Sawano, .

A remark on the tracial Rokhlin property

Zhang, Y. $H$.

Fractional integral operators on $\alpha$-modulation spaces in the full range

Zhao, G., Guo, W. \& $Y u, X$

A simple proof of the strong law of large numbers with rates

Luzia, $\mathcal{N}$.

Abstracts of PhD Theses

The ocean's global iron, phosphorus and silicon cycles: inverse modelling and novel diagnostics

Pasquier, $B$.

Nonstandard estimation for the von Mises Fisher distribution

Ghodsi, $M$.

Nonlinear thermomagnetic instabilities in ferromagnetic nanofluids Dey, $P$.

Author Index for Volume 97 